\title{
THE PUBLIC POLICY OF THE STATE OF PENNSYLVANIA.
}

Disappointed attorneys have been heard to remark tha! when the Court had found there was no real reason to defeat their contention it based its decision upon "public policy". That expression is indeed very vaguely used-like charity, it covereth a multitude of sins.

Public Policy has been defined as "the principle of law which holds that no one can law fully do that which has a tendency to be injurious to the public or against the public good", and again it has been said that public policy is "the principle under which freedom of contract or private dealing is restricted by law for the good of the community". ${ }^{1}$ The latter of these definitions is too narrow, for public policy is not merely a principle of the law of contracts, but extends to a variety of branches of the law. Both clefinitions are vague. IVithout attempting as yet to define our sulbject, let us, after considering both the above definitions, ask the question, what is injurious to the public and what is public good? As soon as these questions are put into words, we find nothing has been gained by defining public policy in the above language. If regard. for the public good were made the sole basis of the resolution of the court, its decisions today would vary more from those of fifty years ago than they do under prescnt conditions, for the ideas of public good and public injury vary as we progress in public wisdom, just as we make material progress more rapidly than does the conservative common law. Therefore if we were to take the above definitions literally, we wouli find we had wholly overlooked the principle of stare decisis.

Another limitation, not expressed in the above definitions, is that the principle of public policy is one of unwritten law. We must therefore conclude that our definitions lack two essentials; firstly, that the principle of stare decisis limits the principle of public policy; and, secondly, that the statute law limits the principle of public policy. In regard to the last statement-which is

${ }^{2} 9$ Cyc 481 .

(84) 
not perfectly self evident-it should be noted, that when any rule of public policy is placed upon the statute books, it ceases to be a rule of public policy and becomes a matter of legislative policy. We are, therefore, probably safe in saying that the term public policy denotes the policy of the courts controlling matters which are not the subject of stibstantive law or of statute, and that such policy once declared will, usually, be followed.

Thus far we have merely cleared the ground. We have not advanced toward securing an answer to our question just what is public policy in the State of Pennsylvania. From a careful classification of the decisions of the. Supreme Court dealing witl this subject, the following generalizations may be made. The public policy of the State of Pennsylvania is addressed to, (I) The preservation of the government; (2) The protection of the administration of justice; (3) The preservation of the Christian religion; (4) The maintenance of public decency; (5) The maintenance of our present customs in regard to the relations of the sexes, or, more specifically, the preservation of the marriage relation; (6) The regulation of private business in accordance with the courts' conception of business morality.

What right the courts have to set up standards of conduct in any of the cases above enumerated except the first two is a question that cannot be answered. It is beyond the scope of this inquiry. We need only consider the fact that such standards have been established. The first two objects of public policy are justifiable, if at all, by the same arguments which justify stable government.

Let us consider seriatim each of the above divisions of our subject with the idea of ascertaining the extent of the principles.

The Preservation of the Government.

Traffic in public office is contrary to public policy. This generalization is to be drawn from four decisions of the Supreme Court. In Filson v. Himes ${ }^{2}$ it was held that a contact with an entire consideration-a part of the promise being that the promisor should use his influence to secure the promisee an appoint-

'5 Pa. 452 (1846). 
ment as postmaster-was unenforcible because part of the promise was contrary to public policy. Gibson, C. J., did not base his decision upon the reason that traffic in public office is contrary to the whole spirit of representative government, but relied upon the analogy of the case before him to earlier cases from other jurisdictions.

In Hunter v. Wolf $f^{3}$ the Sipreme Court decided that a contract between two aspirants to the office of federal assessor that one should withdraw his candidacy and the other, if appointed, would divide the profits of the office, was void. Mr. Justice Sharswood, who delivered the opinion of the court, assumed the point in controversy and stated no reasons for the application of the ban of public policy. Again in IVilkes-Barre v. Rockafcllonc $0^{4}$ it was held that a contract in consideration of a promise of election to office was invalid. Mr. Justice Williams simply says such an agreement is contrary to public policy. And in Fahnestock v. Clark" it was held that a trial of the right to a public office could not be effected by a feigned issue upon a case stated because such a course is contrary to public policy. No reason is given for the application of the ban.

It was held as early as 1843 in Clippinger v. Heplaugh that a contract to infuence legislators to pass a special act of assembly is void. Speaking of services in securing an enactment, Mr. Justice Rogers said:

"We do not say, it is not necessary to the case, to say, that a certain compensation for such services may not be recovered, but we are clearly of opinion that it would be against sound policy to sanction a practice which may lead, to secret, improper and corrupt tampering with legislative action. . .

"It is of first consequence that they [the members of the legislature] should not be deceived, that they should be protected from the arts and misrepresentations of designing men, having an interest to mislead them from the paths of duty. It is, thereiore, most erroneous to assume, as it is generally by the plaintiff's counsel, that a practice, leading to such consequences,

\footnotetext{
71 $\mathrm{Pa} .282$ (1872).

- $171 \mathrm{~Pa} .177$ (1895),

24 Pa. 501 (1855),

5 W. \& S. 315 .
} 
is not contrary to private interests and public morals. The reverse is too true; for already a class of persons has arisen, at the seat of the general government and elsewhere, who make it a business to push private claims for a compensation greatly, if not entirely, dependent upon success. How demoralizing this may be, it needs not the gift of prophecy to foretell, nay, more, we feel its effects, for it is impossible to shut our eyes at the consequence of these, and other causes, daily developing themselves in the decline of justice and public morals. How easy the transition from private individuals to the members themselves, it would not be difficult to divine, but we are not left to conjecture, for we are not without examples, which it would be invidious to mention, but which are too well known."7

In Bouman v. Gofroth ${ }^{8}$ it was decided that it is illegal, because contrary to public policy, to undertake to secure the discharge of a man who had been drafted into the army. Mr. Justice Reed, speaking for the court, said:

"The cases . . . establish that a contract to procure a pardon from the Governor, of a convict, would now be held illegal; whether improper means were used or not; so, to procure the passage of a private statute, or, to procure an appointment to office by private influence, or, to purchase the right ot administration, are held to be illegal and void."

In Holdship v. Jaudon ${ }^{10}$ the Supreme Court decided that a contract to violate a public duty is void, but that a bond conditioned to do a thing contrary to a maxim of law is a single obligation. This ruling was carried to its logical conclusion in Koons v. Seward ${ }^{11}$ in which the court held that a bond given to a plaintiff in a capias ad respondendum, conditioned to produce

'So also in Ormerod v. Dearman, 100 Pa. 56I (1882) and Spalding v. Ewing, $149 \mathrm{~Pa}$. 375 ( 1892 ), the Supreme Court decided that ony interference with the creating of legislation is contrary to public policy.

$59 \mathrm{~Pa}$. 19 (1868).

- Hatzfield v. Guldon, 7 Watts, 152 (1838) - No man would say that if it were possible to procure a pardon by a direct payment to the Governor, it would be lawful to give one. To bribe others, to deceive and impose upon him, only differs in degree". And a contract to corrupt the officers of 2 private corporation is void, Weckerly v. Lutheran Congregation, 3 Rawle, 172 (1831).

16 S. \& R. 307 (1827).

" 8 Watts, 388 (1839). 
the defendant, is an absolute obligation and not contrary to public policy. ${ }^{12}$

It would seem, on principle, that the preservation of the government depends in part upon government officials being compensated according to law, neither more nor less. The resolution of the Supreme Court in Lancaster County v. Fulton ${ }^{13}$ that to compensate a public officer in excess of his lawful emoliuments is contrary to public policy is, therefore, not surprising. ${ }^{14}$ But in Fulton v. Lancaster County ${ }^{18}$ the Supreme Court distinguished the previous case and held that where a public officer, aiter the expiration of his term of office, is re-employed by the proper county authorities to carry on a special duty, he may be compensated in excess of his legal remuneration. As it has been held that to increase the salary of a public officer, is contrary to public policy, so on the other hand it has been held, in other jurisdictions, that to diminish their salaries by attachments is contrary to public policy, but in Pennsylvania that rule is based upon a different consideration.

Mandamus and indeed any other process of law will be denied where the objects sought to be obtained thereby are contrary to public policy. Mr. Justice Gordon in Sterrett v. Electric Reporting Co. ${ }^{16}$ said:

"The writ of mandamus is not of right, but its issue is for the sound discretion of the court, and it ought never to be granted where the object sought to be attained is an immoral one or of pernicious or inmmoral tendency or against public policy."

It was held, in Fox v. Cash, II Pa. 207 (1849), that it is not contrary to public policy for a county clerk to purchase lands sold at public sale for arrears of taxes: but in Weeks v. Lippencott, $42 \mathrm{~Pa} .474$ (1862), it was held to be contrary to public policy to pay money to a man for withdrawing his opposition to the opening of a road through his property.

${ }^{21} 128 \mathrm{~Pa} 48$ (1889).

"To the same effect is McCandless v. Allegheny Bessemer Steel Company, $152 \mathrm{~Pa}$. 139 (1893), although a distinction was there drawn and it was decided that to compensate a deputy sheriff for special services is not contrary to public policy.

"16 $162 \mathrm{~Pa} .294$ (1894).

19 19 Phila. Rep. 386 (1887?). 
It sounds antique in these days of democracy seriously to discuss state secrets, but it was held in Gray v. Pentland ${ }^{17}$ that the courts would not enforce the revelation of secret state documents. ${ }^{18}$

\section{Protection of the Administration of Justick.}

It is obvious that the policy of the courts should be opposed to any obstruction of public justice. It was early held that an agreement to stifle a criminal prosecution is yoid. ${ }^{10}$ The Penal Code subsequently defined the rights of individuals in this respect. ${ }^{20}$ However it is not contrary to public policy for one to go bail for another and to take pay for so doing. ${ }^{21}$

Obstructing justice is also the basis of the line of decisions which hold that a stipulation in a contract which ousts the jurisdiction of the courts is void. ${ }^{22}$ It is difficult to see how this doctrine could be extended beyond the facts of the cited case. In that case there was a stipulation written into the contract that any action on it must be brought in a court of a certain county named in the contract. This would be impossible of enforcement for it could not give the courts of that.county jurisdiction if they had none nor could it oust the jurisdiction of some other conrt lawfully acquired.

The proceedings of jurors cannot be made the subject of inquiry; for it is against public policy to subject jurors to such search. In Quinu v. Crowell ${ }^{23}$ the Supreme Court resolved that a juror could not be examined as a witness concerning the reason for which a majority of the jury favored one side or the other, nor what was the charge of the court. Neither is the testimony of jurors admissible to impeach their verdict. In Clug-

" 2 S. \& R. 22 (1815).

"Hartranfts Appeal, $85 \mathrm{~Pa} .433$ (1877), is to the same effect.

"Stout v. Rassel, 2 Yeates, 334 (1798).

* Act of 3 Ist March, 1860, P. L. 382, §10, makes an agreement to compound a felony unlawful. And Act of I3th of March, 1860, P. I. 427, \$9, provides that a prosecution for a misdemeanor may be settled. Riddle $\mathbf{v}$. Hall, $99 \mathrm{~Pa}$. II6 (I88I), Pearce v. Wilson, III Pa. I4 (1886).

${ }^{21}$ Bing v. Willey, $146 \mathrm{~Pa}$. 381 (1892).

Healy v. Building and Loan Association, 17 Pa. Super. Ct. 385 (1901).

4 Wharton, 334 (1839). 


\section{gage v. Swan'24 Mr. Justice Yeates delivered a lengthy and lucid opinion upon this point, saying in part:}

"Independently of all authorities on the subject, it is manifest that the finding of a jury should be the result of their impartial and unprejudiced judgment according to the evidence. The decision of a contested case by lot must be reprobated by every honest man. . . . The difficulty which here presents itself is how shall the fact be established? Shall one or more of the jurors be permitted by their voluntary affidavits to ascertain that they and their fellows have so grossly misbehaved themselves and perverted the very object of their high office? I frankly confess that I feel the utmost repunan offe? . . timony, although I am fully atmost repugnance to such tesmost the only by admitting it door to the it, I as readily perceive, that I should open the with jurors and the of the most pernicious arts, and tampering consequences. Jurors who hould be replete with dangerous firmed to give a verdict according to the sworn or solemnly afgrace into a tribunal of justice to the evidence come with bad grace into a tribunal of justice to prove their own dishonorable heard in their defence. the practice if adopted would tend to ano all I greatly fear that consciences of jurors as to the grounds and inquisition over the dict and bring questions the grounds and reasons of their vercourt for their decisions than is consistent with sound the

\section{${ }^{2} 4$ Binney, 150 (1811).}

The rule here under discussion has been considered recently in Commonwealth v. Bergdoll, $55 \mathrm{~Pa}$. Super. C.. I86 (I913). - In that case Judge Swartz,

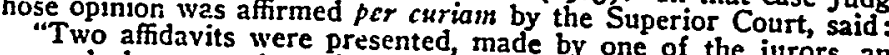

was made by a member of the bar made by one of the jurors, and a third It is claimed that these affidavits show heard this juror make a statement. tion a matter that was not in evidence, that the jurors took into considerarendering their 'verdict.

"We did not allow these ex parte affidavits to be flef impeach his verdict by this method, affidavits to be filed. If a juror may and few verdicts could stand. The court a trial is of little conseguence, same case. Out of a panel of twelve men any be kept busy in retrying the to find one juror who can give some plausible persistent attorney is likely for not finding a verdict as counsel plausible irrelevant matter as an excuse

"The rule of" law, that one to impeach the verdict of the jury on the ground that som, cannot be allowed an unfair argument before his fellows, is well established far, that a juror's testimony is not admissible as to what The rule goes so deliberation of the jury acting as an armissible as to what transpired in the official duty.

"It is clearly agananst public policy to admit such evidence. A relaration of the rule would subject the jurors to the importunities and A relaxation 
.. . The settled rule in New York and Virginia as well as the most modern English authorities are adverse to receiving such testinony and I cannot discover why we should be more inattentive to the reputation and feelings of our own jurors."2s

Cluggage v. Swan has been limited by Huidecoper v. Cotton $^{20}$ where it was held that a grand juror might be permitted to testify who was the prosecutor in a bill of indictment which had been returned ignoramus.

The principle of forbidding a juror to stultify the verdict has been extended somewhat. Thus in Brechtel v. Cortright 27 it was held that the sheriff having made a specific return is not a competent witness to contradict it. But in Stewart v. Chester \& Darby Road $\mathrm{Co}^{28}$ it was decided that an arbitrator is not disqualified to testify as to the physical condition of a plaintiff whose case had been tried before arbitrators. Nor is a person to be excluded as a witness in a road case because he had been one of the viewers. ${ }^{29}$

While the jury system was originally founded upon the theory that the jury of the vicinage ought to be acquainted with the facts and therefore come to a true saying (verdict), it is customary today-particularly in criminal cases-to endeavor to exclude from the jury all persons who know anything about the case. While it was held in Howser v. Commonzealth ${ }^{\mathbf{s 0}}$ that a juror is a competent witness either in a civil or criminal case, Mr. Chief Justice Woodward said: "As to material witnesses, those, we mean, upon whose testimony the event is essentially dependant, we think they ought not to be admitted to the jury box." This principle he bases upon sound policy, not upon the constitu-

interested parties, after the verdict, and involve the jurors in controversies among themselves as to what actually occurred in the jury room, with a possible tendency to perjury."

* As to the case of Bradley v. Bradley, 4 Dallas, Ir2 (1792), which seems to be contrar,' to Cluggage v. Swan, Mr. Justice Yeates says (p. 136): "That case is reported erroneously. I was of counsel with the plaintiff." - .

$*_{3}$ Watts, 56 (1834).

" 13 Pa. Super. Ct. 384 (1900).

3 Pa. Super. Ct. 86 (1896).

* Plank Road v. Thomas, 20 P2. 91 (1852).

${ }^{4} 51 \mathrm{~Pa} 332$ (1865). 
tional right of the accused to be confronted with the witness against him. ${ }^{81}$

While the courts have been very tender to jurors and have refused to permit the sheriff to contradict his return, they have, in spite of their professed tenderness toward arbitrators, been rather strict with them.

It was not always so, for in Wade v. Gallagher ${ }^{32}$ it was resolved, after long argument, that referees could not be examined as to their proceedings. "You may examine referees as to a plain simple point, as, did they allow interest on an unsettled account, or the like, but to go further would supersede the use of all references." The thought thus expressed was still influential with the court in Ellmaker v. Buckley ${ }^{33}$ wherein it was decided that an arbitrator was not only not competent to give evidence of his own misconduct and that of his brethren, but that he might not testify to the misconduct of one of the parties before him, if such evidence, at the same time, involved the misconduct of the arbitrators.

This line of cases ends with Ellmaker v. Buckley. Two years later a different influence enters and Roop v. Brubacker ${ }^{34}$ is the opening wedge. It was then held that one of the arbitrators was competent to prove that certain matters were not considered by them and that consequently their award was a mistake. "To put the sanctity of an award on the highest ground ever assumed, it is no greater than a judgment of a court; but a judgment is not conclusive of any matter not in contest and not decided on." It is true that in this case the amount of land in dispute had never been questioned before the arbitrators and that "one of the arbitrators who re-surveyed it was as competent a witness as any other man, to prove the real quantity" which is perfectly sound; but the learned judge adds-purely by way of dictum - what was not the law in Pennsylvania when he

r Yet in Harper v. Kean, II S. \& R. 280 (1824), a witness who had been examined before the arbitrators in the first trial of the cause was sworn as $a$ juror, and the judgment was affirmed.

I Yeates, 77 (1791).

I6 S. \& R. 71 (1827).

* I Rawle, 304 (1829). 
said it, "the arbitrators may be examined to prove whether a matter was acted on by them or to prove a mistake made. by them".

In Perit v. Cohen ${ }^{35}$ the plaintiff called one of the arbitrators merely to prove the submission and the award. On cross-examination, he was asked whether or not the arbitrators had not, prior to the award, decided that they could make no award and so notified the parties. This was objected to and the overruling of the objection was assigned as error on appeal. Mr. Justice Kennedy said:

"The object of the question by the defendant, was, to ascertain from the witness, whether the submission, of which he spoke in giving his evidence in chief, had not in effect been terminated or put an end to before the award, of which he also testified, was made. Now it is perfectly obvious, that the award was a mere nullity or in law no award at all, unless a submission authorizing it was in force or being at the time it was made"

All of this statement is perfectly true, but it is no reply to the cogent reasoning of Mr. Justice Yeates in Cluggage v. Swar ${ }^{\text {se }}$ with which Mr. Justice Kennedy did not deal. ${ }^{87}$.

The report of Graham v. Graham ${ }^{38}$ preserves a remarkable opinion by Gibbons, C. J. As to the competency of arbitrators as witness he says:

"The objection to the competency of the arbitrators and umpires as witnesses, is unfounded. It is well settled that an arbitrator may prove facts that came under his notice in the progress of the proceeding the only question being whether he is bound to testify. . . . The point is still unsettled and as it does not arise in the case before us, we say no more than that, as the witnesses did not refuse to be sworn, no one else could object to it."

The statute law, prior to 1887 ; did not forbid attorneys from testifying to confidential communications with their cli-

" 4 Wharton, 81 (1839).

- Supra, note 24

- Converse v. Colton, $49 \mathrm{~Pa}, 346$ (1865), is in line with the cases just mentioned. It was there decided that an arbitrator is competent to prove that the award in the proceeding before him was only intended to cover a small portion of the claim sued before the jury.

\% P2. 254 (2848). 
ents. Before the Evidence Act, ${ }^{39}$ however, public policy forbade the disclosure of professional secrets. In Beltzhooz'er v. Blackstock $^{40}$ MIr. Justice Sergeant said:

"As to the other point, the refusal to compel Mr. McDonald to answer the question proposed to him by the defendant, it seems that he possessed no knowledge on the subject except what he obtained from inis professional intercourse with the parties. This it is the privilege of the client he should not be permitted to divulge. Without such a privilege the confidence between client and advocate so essential to the administration of justice would be at an end. It is not necessary there should be cause depending in court; it is sufficient if the witness were consulted professionally and acted, or advised as counsel."'1

It is clear that it is of the highest importance that judicial sales should be untrammelled, for in many cases the judicial sale is the only means of enforcing a judgment of the court. The earliest case upon this subject is Myers v. Hodges ${ }^{42}$ where an administrator contracted to sell a piece of land at a given price. The case arose prior to the enabling acts which permit administrators to sell their decedent's real estate at private sale. Mr. Justice Scrgeant simply points out that the administrator must sell at public sale and adds "the policy of the law . . . requires that public sales shall be fair and free". In Slingluff v. Eckel ${ }^{43}$ a bidder at sheriff's sale promised to pay a judgment held by another bidder if the latter would omit bidding and the former succeeded in purchasing the property. The contract was held void. Black, J., said:

"Can this contract be enforced? Is it not against public policy as well as good morals and therefore void? We all think it is. A debtor, whose property is taken in execution, has a right to have it sold for the highest price that it will bring."

-Act of 23rd of May, 1887, P. L. I58.

- 3 Watts, 20 (1834).

"The doctrine here laid down was affirmed and somewhat broadened in Moore v. Bray, $10 \mathrm{~Pa}$. 519 (1849), and Kaut v. Kessler, $114 \mathrm{~Pa}$.603 (1886), but the matter has now been placed on the statute books so that attorneys are now forbidden to disclose their clients' secrets by statutory enactment and not by public policy.

2 Watts, $38 \mathrm{r}$ (1834).

: $24 \mathrm{~Pa} .472$ (1855). 
This reasoning, based, as it is, on the rights of the judgment debtor, seems to have impressed the court in Maffet $v$. Ijans $^{44}$ where it was decided that a contract between several judgment creditors, to stifle bidding at a sheriff's sale, which was agreed to by the execution defendant and all the creditors who would be affected by the sale was not contrary to public policy. It is difficult to reconcile this case with previous dicta. Yet in Bartonv. Benson ${ }^{45}$ two lien creditors whose judgments together amounted to more than the value of the land to be sold agreed to stifle bidding at an Orphans' Court sale, without notifying the deceased defendant's heirs. Upon this narruw ground the court distinguished Maffet v. Ijams. ${ }^{48}$

\section{The Preservation of the Caristian Religion.}

Blackstone tells us, with pride, that Christianity is part of the common law. The Christianity of King Henry V's time was very different from the Christianity of today. So was the common law. It is difficult to say which of the two is the more conservative. Few reported decisions, however, made the preservation of the Christian faith the basis of the resolution.

The case of Zeisszeiss v. James ${ }^{47}$ where a trust to found an infidel institution was struck down, is too familiar to need much elucidation. However in Manners v. Philadelphia Library Co. ${ }^{48}$ it was held that the mere fact that atheistic books, were, under the terms of the will, to be kept in the library, did not vitiate the bequest.

The facts of Kright's Estate ${ }^{49}$ are interesting. A decedent by his will bequeathed money to the "Friendship Liberal League", which was an organization opposed to all "isms" and

${ }^{4} 103 \mathrm{~Pa} 266$ (1883).

- $126 \mathrm{P2}$. 431 (1889).

* The distinction is fine spun, and cither Maffett v. Ijams is right or it should be overruled. Barton $v$. Benson draws so fine a distinction that it would be invidious to call attention to the fact that it is a per curiam opinion. Hays' Estate, $159 \mathrm{~Pa} .38 \mathrm{I}$ (1893), is another per curiam opinion, following the ruling.

63 P2. 465 (1870).

$93 \mathrm{~Pa} .165$ (1880).

* 159 Pa. 500 (1894). 
devoted to the investigation of the truth. Sometimes lectures against Christianity were delivered at meetings of the league. The Supreme Court very liberally called the league a religious or charitable society.

In Prince of Peace Hospital ${ }^{50}$ there is an inference that a charter for a corporation of the first class was refused because, if granted, the work of the hospital for which the charter was sought would controvert a fixed tenet of the Christian religion; ${ }^{51}$ but there is also an inference that the decision was based upon a desire to maintain public decency.

In First Church of Christ, Scientist, ${ }^{52}$ the Supreme Court affirmed the decree refusing a charter to a Christian Science Church. Though the decision is based upon the reason that the nembers of the church proposed to practice medicine without a license, there is an inference that the maintenance of present-day Christianity was the real motive for the decision.

The Maintenance of Public Decency.

In reported opinions from other jurisdictions, judges have made a great point of sustaining public decency. Who is to determine what is public decency and by what standard it is to be weighed, has not been made apparent. Aside entirely from the statute law, which covers considerable ground under the heading, there seems to be but one reported decision upon the point in Pennsylvania. This is Prince of Peace Hospital ss already referred to. In that case application was made for a charter for a corporation intended to maintain a hospital to take care of indigent unmarried women during childbirth. The charter was refused on the ground that public policy forbids such a public indecency.

The Preservation of the Marriage Relation.

The kind of Christianity dispensed by the courts in general, holds as one of its dearest tenets that marriages are made in

“ II Pa. Dist. Rep. 242 (I900).

"See infra, note 52.

- $205 \mathrm{~Pa} .543$ (1903).

- Supra, note 49. 
heaven. Anything detrimental to the institution of marriage is contrary to public policy. Thus a contract not to oppose a divorce suit was held void in Kilborn v. Field, ${ }^{54}$ Mr. Justice Sharswood saying:

"Causes for divorce 'being recognized by law' we are to take it that the true philosophy of life, the ends of justice and the interests of society, are best promoted by allowing the dissolution for such recognized cause. Courts, however, ought to be careful to see that all requirements of the law in such proccedings be complied with, both as to form and subseance, so that divorces may never be obtained through levity or collusion. Such then being the clear policy of the law, every contract founded upon a consideration in contravention of it must according to well settled principles be void."

But merely dealing with the domestic relation, if not to its detriment, is not unlawful. Thus to contract with a stranger to use only a certain ground for divorce in a suit against one's spouse is not void. ${ }^{55}$ Nor is a contract to support a married woman who has been deserted by her husband. ${ }^{50} \mathrm{~A}$ contract in consideration of past cohabitation to marry a woman and not to desert her is enforcible. 57

As attorneys are forbidden by statute from testifying to their clients' secrets, so husbands and wives are forbidden by our Evidence Act from revealing connubial confidences. But prior to this act public policy provided the same rule. Mr. Justice Reed in Hitner's Appeal's said:

"The reason for excluding the husband and wife from giving evidence either for or against each other is founded partly on their identity of interests and partly on a principle of

$478 \mathrm{~Pa} .94$ ( 1875 ).

*Irwin v. Irwin, 169 Pa. 529 (1895).

- Enders v. Enders, I64 Pa. 266 (1894):

"Wyant v. Lesher, $23 \mathrm{~Pa} .338$ (1854), "In what does the imagined illegality of the consideration of this bond consist? Is it immoral for a seducer to provide for the victim of his passions and the offspring of their guilt? illegal for a suitor to propitiate parental consent to a daughier's marriage by $a$ promise that he will live with and treat her as a kind and affectionate husband ought? It would be a disgrace to our age and generation if the law compelled an affirmative answer."

${ }_{54} \mathrm{~Pa}$. 110 (1867). 
public policy which deems it necessary to guard the security and confidence of private life even at the risk of an occasional failure of justice:"

A contract to devise in restraint of marriage is against public policy. ${ }^{\text {so }}$.

\section{Regulation of Private Business.}

By what authority the rules hereafter discussed have been laid down by the courts has nowhere been made to appear, but it is certain that public policy has been the excuse for much judicial legislation. It has been thought wise by the judges to enforce a certain code of morality in private business and they have interfered to the extent of laying down certain standards quite foreign to the ordinary principles of substantive law. A radical critic of the Supreme Court decisions bearing upon this subject would declare that while the interference is wholly unwarranted and has usually been directed to the support of the predatory portion of the community, it has not always been unjustifiable. A conservative critic of these decisions would say that the courts have not interfered enough. Disinterested consideration of the decisions leads inevitably to admiration of Adam Smith, for the doctrine of laisser faire permeates much of the learning on this branch of our subject. There can be no doubt that interference with the right of freedom of contract is radical, but the interference exercised by the courts has been reactionary, not radical, and yet this criticism is more academic than real for it is hardly possible to argue in favor of the actions forbidden by public policy.

The following matters have been made the subject of interference: Trade secrets, restraint of trade, combinations and monopolies, breach of trust, public corporations, wagering, and life insurance.

It has been held that it would be immoral for a man to learn the trade secrets of another in that other's employ and then injure him be revealing them. Their narration was not compelled in Philadelphia v. McManes ${ }^{60}$ where Judge Allison said:

- Schacfer v. Senseman, 125 Pa. 310 (1889).

' 17 Phila. Rep. 75 (1885). 
"The discovery or acquirement of a special mode of accomplishing definite results in art or in manufactures or in that which may be of value to the lawful possessor of such discovery, may be protected as the special property of the owner, which he may not be required to reveal to others."

Restraint of trade itself could be made the subject of a much longer essay than this, but a detailed study of this topic is not within the scope of this article. We need but briefly to outline the bearing of public policy on this subject. In Koeler v. Tay$\operatorname{lor}^{61}$ it was ruled that a restraint of trade, if nothing more ap. pear, is void. But Mr. Chief Justice Woodward rested his opinion not so much upon public policy as upon the substantive law giving authority and not reason for his decision. ${ }^{62}$ Partial or limited restraints of trade have always been upheld. Thus to restrain trade in a particular locality is not contrary to public policy ${ }^{68}$ nor is a total restraint for a limited time, such as a year. ${ }^{\text {B4 }}$

In Morris Run Coal Co. v. Barclay Coal Co. ${ }^{\text {os }}$ five coal companies combined to destroy competition and equalize the price of coal. One of them having broken the contract, one of the others endeavored to enforce it. The court, however, refused to lend its aid and Mr. Justice Agnew, who delivered the opinion, said:

"The effects produced on the public interests lead to the consideration of another feature of great weight in determining the illegality of the contract, to wit: the combination resorted to by these five companies. Singly each might have suspended deliveries and sales of coal to suit its own interests, and might have raised the price, even though this might have been detrimental to the public interest. There is a certain freedom which must be allowed to every one in the management of his own affairs. When competition is left free, individual error or folly will generally find a correction in the conduct of others. But here is a combination of all the companies operating in the

* 53 Pa. 467 (1866).

- The opinion of Taylor v. Senseman, IIo Pa. St. 3 (1885), adds nothing to the discussion, except in so far as it is said that a contract in restraint of trade is contrary to public policy.

- McClung's Appeal, 58 Pa. 51 (1868) ; Kelso v. Reid, 145 Fa. 606 (1892); Patterson v. Glassmire, $166 \mathrm{~Pa}$. 230 (1895).

" Fuller v. Hope, I63 Pa. 62 (1894).

- 68 Pa. 173 (1871). 
Blossburg and Barclay mining regions, and controlling their entire production. They have combined together to govern the supply and the price of coal in all the markets from the Hudson to the Mississippi rivers, and from Pennsylvania to the lakes. This combination has a power in its confederated torm which no individual action can confer. The public interest must succumb to it, for it has left no competition free to correct its baleful influence. When the supply of coal is suspended, the demand for it becomes importunate, and prices must rise. Or if the supply goes forward, the price fixed by the confederates must accompany it. The domestrt hearth, the furnaces of the iron-master, and the fires of the manufatturer, all feel the restraint, while many dependent hands are paralyzed and hungry mouths stinted. The influence of a lack of supply or a rise in the price of an article of such prime necessity, cannot be measured. It permeates the entire mass of community, and leaves few of its members untouched by its withering blight. Such a combination is more than a contract, it is an offense."

In Nester v. Brczoing $\mathrm{Co}^{68}$ upon a similar state of facts $\mathrm{Mr}$. Chief Justice Sterrett said:

"The test question, in every case like the present, is whether or not a contract in restraint of trade exists which is injurious to the public interests. If injurious, it is void as aganst puulic policy. Courts will not stop to inquire as to the degree of injury inflicted. It is enough to know that the natural tendency of such contracts is injurious. . . " (Page 23.)

"The appellants insist that restrained trade in the necessaries of life only is within the prohibition of public policy. No standard has been furnished by which to ascertain what constitutes these with reference to the general public."

The rule that such a combination is contrary to public policy extends beyond the mere refusal to enforce the contract of combination. The state will inquire by summary proceedings into such contracts. ${ }^{\text {or }}$

Breach of trust, even though it involves no crime or civil injury. is contrary to public policy. A contract in consideration of relinquishing the right to administer a decedent's estate is void. ${ }^{68}$ In Everhart v. Scarle ${ }^{60}$ one Flagg employed a certain

* ${ }_{16 \mathrm{I}}$ Pa. 473 (1894).

"Commonwealth v. Delaware \& Hudson Canal Co., 43 Pa. 295 (1862).

"Bowers v. Bowers, $26 \mathrm{~Pa} .74$ (1856).

71 Pa. 256 (1872). 
Searle to sell some land. Everhart, the plaintiff-in-error, agreed to pay Searle five hundred dollars "for services in assisting to negotiate a purchase". of the same land. Although the sale was made at a price higher than Flagg had authorized Searle to sell for, nevertheless the court held that Searle's contract with. Everhart was contrary to public policy.

Public corpnrations are no more exempt from breach of trust than private individuals, but the peculiar nature of their trust perhaps justifies their treatment under a separate heading.

In Crescent Steel Company v. Equitable Gas Company 70 company incorporated under the Act of May 29th, 1889, to supply the public with natural gas, entered into a contract to give its directors and stockholders a preference or priority in the supply. This was held contrary to public policy because it interfered with the defendant's duty and could not be enforced.

In Vanderbuilt v. Bennett ${ }^{71}$ a voting trust agreement between stockholders of a railroad was under consideration. This the master stigmatized as a combination openly formed for the purpose of absolutely controlling the interests and policy of a great public corporation so as to best suit the interests of those in the scheme, wholly regardless of the interests and rights of the other stockholders and the welfare of the. public. And Judge Stowe, in affirming the report, said: "We think that the trust agreement is absolutely void as contrary to public policy."

Wagering was not illegal per se at common law. The earliest case on the subject in Pennsylvania goes no further than the common law rule and merely holds that a wager concerning a human being is void. ${ }^{32}$ Edgell v. McLaughlin ${ }^{78}$ goes a great deal further. Mr. Justice Sergeant, in holding no wager can be recovered on, said:

"When I look back to the character and principles which actuated our founders and predecessors, I am satisfied they never countenanced such a principle, but left parties who chose to embark into contracts of this kind, to recover as they could,

$" 40$ Pitts. I. J. (O. S.) 316 ( 1892 ).

" $6 \mathrm{~Pa}$. C. C. Rep. I93 (188\%).

Phillips v. Ives, I Rawle, 36 (1828).

" 6 Wharton, 176 (184). 
according to the code of honor under which they originated; and that it is derogatory to the character and injurious to the inIcrests of the community, to sanction them. and to employ their lcgal tribunals in investigations often indecent, often inflammatory, often impertinent and frivolous, and always useless, if not noxious in their effects on sociéty."

Since all wagering contracts are contrary to the public policy of the Conunonwealth of Pennsylvania a fortiori stock gambling is illegal. In Brua's Appeal ${ }^{74}$ the auditor held that the whole transaction was gambling and therefore void, but the Supreme Court said that while it was true that a contract based solely upon the rise and fall of the market and not contemplating a delivery of the securities presumptively dealt in is roid, in this particular case the buyer really purchased shares of stock and the cointract was therefore valid. ${ }^{75}$

Phillips v. I $z^{\prime} \mathrm{cs}^{78}$ is the basis of the court's interference with life insurance. In that case a wager was made as to whether $\mathrm{Na}$ poleon Bonaparte would escape from St. Helena and this the court held void because it was a wager concerning human being. Downey v. Hoffer ${ }^{77}$ is a typical case showing this rule in its full fruition. It is, namely, that life insurance is void unless there is an insurable interest. It is beyond our subject to discuss what is an insurable interest.

Having now considered all the cases dealing with the subject of public policy and endeavored to classify them, we find that we have traveled in a circle and are confronted with the same question which presented itself at the outset. We have seen that definition does not answer this question for it simply shifts the ground of inquiry. We have endeavored to classify the authorities, however, and should now be in a position to draw

"55 Pa. 294 (1867).

" Subsequent cases have added but little from the point of view of public policy thougli they have added much from the standpoint of stock gambling. Fareira v. Gabell, $89 \mathrm{~Pa}_{2} 89$ (1879), simply holds that the bona fides of a transaction in stocks is for the jury; Gaw v. Bennett, $153 \mathrm{~Pa} .247$ (1893), turned the dicta of earlier cases into law, the jury having found the note was void: while Taylor's Estate, $192 \mathrm{~Pa} .309$ (1899), and Macdonald v. Gusler, $208 \mathrm{~Pa}$. 177 (1904), have really added nothing.

"Supra, note 72.

"1 10 Pa. 109 (1885). 
from them generalizations to give a catagorical answer to the question what is the policy of our courts? It is impossible to carry the generalization to a single proposition. It may be said that there are several policies not inconsistent because covering different subject matters. These will be epitomized in the order of the analysis of the anthorities we have heretofore made.

The preservation of stable government is a prime object of . judicial solicitude. This end is sought by discouraging traffic in public office, encouraging the probity of public officials, encouraging the performance of public duties, assuring to public officials no more and no less than their legal emoluments and protecting state secrets from revelation. Traffic in public office has been discouraged by refusing judicial sanction to all contracts of traffic in public office whether they be in the form of promises in consideration of election or appointnent thereto or of submitting the title thereto to extra legal decision-even though such decision be asked from court. Probity of public officials has been encouraged by excluding from judicial consideration and declaring void all contracts tending to the corruption of public officials even though such contracts were not made with the officers intended to be corrupted and even though the contracting parties did not have in view bribery, but merely influence where such influence was deemed to be undue by the courts before which the contract was sought to be enforced. The performance of public duties has been enconraged to the extent that any contract made in consideration of a violation of a public duty was declared void. Public officials have been assured their legal emoluments by the refusal of the courts to lend the aid of their process to any method of increasing them, the diminution thereof by attachment or sequestration is forbidden by statute in Pennsylrania and is therefore not the subject of judicial policy. State secrets have been protected from revelation to the extent of refusing the use of legal machinery to those seeking to compel disclosure.

The protection of the administration of justice is another firmly established policy of our courts. The means by which this end has been sought have been by overriding all efforts at obstructing public justice; keeping secret the proceedings of the 
jury room, and excluding material witnesses therefrom, although arbitrators do not seem to share the protection afforded jurors; and insuring fairness of judicial sales.

Another policy of our courts seems to be the preservation of present day Christianity. All contracts derogatory thereto are held void as are legacies or devises to ends tending to its destruction or to bring it into disrepute.

The maintenance of public decency is promoted by placing a ban upon all transactions which controvert it even though they do not viclate any statute.

The preservation of the marriage relation in its present status is a well established policy of the court of this Commonwealth. To this end provisions in contracts or wills in restraint of marriage or encouraging the dissolution of an existing marriage are not enforceable, while settlements of connubial difficulties and transactions tending to preserve or foster marriages are encouraged.

Finally it is judicial policy to force upon the community a code of business morality drawn, indeed, from no authoritive source, but generally in accord with public opinion. To accomplish this end, the revelation of trade secrets will not be compelled; legal sanction is refused to all unreasonable restraints of trade; combinations looking toward monopoly are not only not enforceable, but are subject of inquiry and prohibition at the suit of the State; breach of trust whether by an individual or by a private or public corporation renders all contracts in consideration thereof void; the creation of corporations for immoral, illegal or improper purpeses will not be permitted, nor may any corporation enact by-laws contrary to accepted theories of morality and ethics; and wagering in any form is forbidden. Under the prohibition of wagers, stock gambling and life insurance, where there is no insurable interest may be classified.

\section{Philadelphia.}

Graham C. Woodward. 